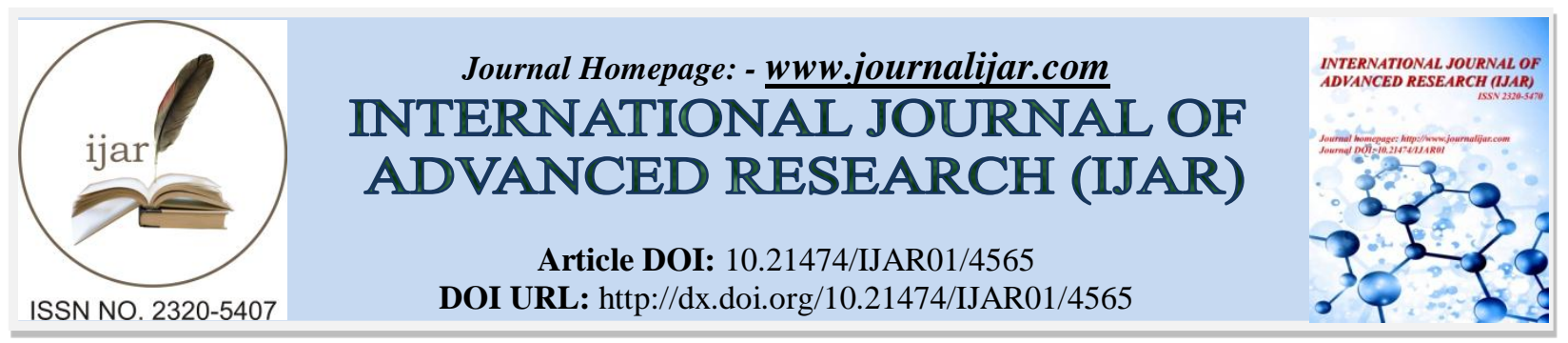

RESEARCH ARTICLE

\title{
A STUDY ON CUSTOMER SATISFACTION TOWARDS CREDIT CARDS WITH SPECIAL REFERENCE TO PRIVATE SECTOR BANKS IN SIVAKASI.
}

Mrs. R. Maheswari. M.Com(CA). M.Phil. D.I.T ${ }^{1}$ and Dr.T.Palaneeswari. M.Com. M.Phil. Ph.D ${ }^{2}$. 1. Ph.D. Research Scholar, Assistant Professor of Commerce, SFR College for Women, Sivakasi.

2. Associate Professor of Commerce, SFR College for Women, Sivakasi..

\section{Manuscript Info}

Abstract

\section{Manuscript History}

Received: 22 April 2017

Final Accepted: 24 May 2017

Published: June 2017

\section{Introduction:-}

Credit cards are fundamentally different from the other payment methods in that they involve extending credit rather than drawing on an existing store of funds. Banks in conjunction with credit card associations such as Visa and Master card, issue general-purpose credit cards. Department stores also issues credit card to be used for purchases at that particular store. Like Electronic Fund Transfer, payment by credit card is not anonymous. Since paying with a credit card does not involve a store of funds, deposit insurance and reserve requirements are not directly relevant. The bank that issues the card is liable and thus merchants are paid if the cardholders default. If the issuing bank fails, the credit card association guarantees payment to merchants with outstanding transactions and then has a creditor's claim on failed banks.

A credit card is part of a system of payments named after the small plastic card issued to users of the system. The issuer of the card grants a line of credit to the consumer (or the user) from which the user can borrow money for payment to a merchant or as a cash advance to the user. A credit card is different from a charge card, where a charge card requires the balance to be paid in full each month. In contrast, credit cards allow the consumers to 'revolve' their balance, at the cost of having interest charged. This study focus on the demographic profile of the respondents, details of banking transactions, utility of usage of credit cards by the card holders, reasons for using credit cards and level of satisfaction towards credit cards.

\section{Review Of Literature}

The credit card helps to identify the important variable in the system such as balance payable, credit card purchase, interest charges and other payments (Manas Ratha, 1997). The technology has played an important role in the development of efficient and secure payment system and will continue to create a chequeless, cashless, society with wireless technology (Narindra Kumar Bhasin, 2009). The E-Banking technology became the engine for triggering rapid change. The current IT tools explicabilities in the bankings are, Credit Clearing System, Debit clearing system, RTGS, SFMS, SWIFT, Plastic Money (Debit cards, Credit Cards, Smart Cards, Contactless Smart Cards), ATM, Echeque, Mobile Phone Banking, Biometric ATM for rural India and others. (Swati Anand , 2010). Many people

Corresponding Author:- R. Maheswari.

Address:- Ph.D. Research Scholar, Assistant Professor of Commerce, SFR College for Women, 
have knowledge about credit cards, but do not possess credit cards because of the fear of falling into debt trap. High income earners and highly educated class use credit cards more, availing high credit limits (Dr.S.Sudhagar, 2012).

\section{Statement Of The Problem:-}

Credit cards have changed the way people look at money. Gone are the days when only the rich sported them at limited counters in select cities. Today, they are a way of life for the middle class too, even in smaller locations across the country. However, this boom has brought in a lot of complications like credit card fraud, payment defaulting, unsolicited card and uncontrolled. As every service is internet bound in the present scenario, the researcher is interested in bringing out the customer satisfaction towards credit cards. With this emphasis the researcher has chosen this topic

\section{Objectives Of The Study:-}

The main objectives of the present study are outlined below

* To measure the level of satisfaction of credit card holders.

* To offer suggestions for further improvement.

\section{Hypotheses}

Hypothesis is a tentative proposition formulated for empirical testing. The study is explorative in nature. In order to achieve the objectives of the study, the researcher has framed the following hypotheses:

* $\mathrm{H}_{0} 1$ : There exists no significant difference between the Gender and the level of satisfaction towards credit card services.

* $\mathrm{H}_{0} 2$ : There exists no significant difference between the Age and the level of satisfaction towards credit card services.

* $\mathrm{H}_{0} 3$ : There exists no significant difference between the Marital Status and the level of satisfaction towards credit card services.

* $\mathrm{H}_{0} 4$ : There exists no significant difference between the occupation and the level of satisfaction towards credit card services.

* $\mathrm{H}_{0}$ 5: There exists no significant difference between the income and the level of satisfaction towards credit card services.

\section{Methodology:-}

The study is based on both primary and secondary data.

\section{Primary Data:-}

The primary data needed for this study is collected from the sample customers through structured questionnaire.

\section{Secondary Data:-}

The Secondary data needed for study is collected from various magazines, articles published in newspapers and surfing through network.

\section{Sampling Design:-}

In Sivakasi, an industrial town, TMB, Axis Bank, ICICI Bank, HDFC Banks and City Union Bank are prominently providing Credit Cards. From these five banks, the respondents will be interviewed for the study. From each bank 30 customers are contacted by applying convenient sampling method. Businessman, Salaried, Professional, Government Employees and House-wives are given due weightage in identifying the sample.

\section{Statistical Tools:-}

The researcher has applied statistical tools such as Percentages, Chi-square test, Scaling Techniques and Garrett Ranking to analyse the collected data.

\section{Findings:-}

\section{Demographic Profile Of The Respondents:-}

The demographic profile of the respondents was obtained by using five parameters namely gender, age, marital status, occupation and monthly income. The same is presented in the Table 1 
Table 1:- Demographic Profile of the respondents

\begin{tabular}{|c|c|c|c|}
\hline Factor & Particulars & Number of Respondents & Percentage \\
\hline \multirow{3}{*}{ Gender } & Male & 95 & 63 \\
\hline & Female & 55 & 37 \\
\hline & Total & 150 & 100 \\
\hline \multirow[t]{5}{*}{ Age (in years) } & Below 30 & 33 & 22 \\
\hline & $30-40$ & 65 & 43 \\
\hline & $41-50$ & 37 & 25 \\
\hline & Above 50 & 15 & 10 \\
\hline & Total & 150 & 100 \\
\hline \multirow[t]{3}{*}{ Marital Status } & Married & 105 & 70 \\
\hline & Unmarried & 45 & 30 \\
\hline & Total & 150 & 100 \\
\hline \multirow[t]{6}{*}{ Occupation } & Businessman & 52 & 35 \\
\hline & Private Employee & 42 & 27 \\
\hline & Government Employee & 20 & 13 \\
\hline & Professionals & 18 & 12 \\
\hline & Housewives & 20 & 13 \\
\hline & Total & 150 & 100 \\
\hline \multirow{5}{*}{$\begin{array}{l}\text { Monthly Income } \\
\text { (in Rs.) }\end{array}$} & Less than Rs.5000 & 33 & 22 \\
\hline & Rs.5000 to Rs. 10000 & 35 & 23 \\
\hline & Rs. 10001 to Rs. 15000 & 47 & 32 \\
\hline & More than Rs. 15000 & 35 & 23 \\
\hline & Total & 150 & 100 \\
\hline
\end{tabular}

Source: Primary Data

Table 1 reveals that a majority of 63 per cent of the respondents are male; a majority of 43 per cent of the respondents fall under the age group of 30- 40 years; a majority of 70 per cent of the respondents are married; 35 per cent of the respondents are businessman; 32 per cent of the respondents fall under the income scale of Rs.10,001 to Rs. 15,000 .

\section{Details Of Banking Transactions:-}

The details of banking transactions were obtained by using four parameters namely type of account, purpose of account and period of operating the bank account and frequency of visit to the bank in a week. The same is exhibited in the Table 2

Table 2:- Details of Banking Transactions

\begin{tabular}{|c|c|c|c|}
\hline Variable & Particulars & Number of Respondents & Percentage \\
\hline \multirow[t]{4}{*}{ Type of Account } & Saving A/C & 87 & 46 \\
\hline & Current $\mathrm{A} / \mathrm{C}$ & 65 & 35 \\
\hline & Fixed Deposit A/C & 33 & 19 \\
\hline & Total & $185^{*}$ & 100 \\
\hline \multirow[t]{3}{*}{ Purpose of Account } & General Purpose & 95 & 52 \\
\hline & Commercial Purpose & 87 & 48 \\
\hline & Total & $182 *$ & 100 \\
\hline \multirow{5}{*}{$\begin{array}{l}\text { Period of Operating the } \\
\text { Bank Account }\end{array}$} & Below 1 year & 31 & 21 \\
\hline & 1 year to 3 years & 44 & 29 \\
\hline & 3 years to 6 years & 51 & 34 \\
\hline & More than 6 years & 24 & 16 \\
\hline & Total & 150 & 100 \\
\hline \multirow{5}{*}{$\begin{array}{c}\text { Frequency of visit to the } \\
\text { bank in a week }\end{array}$} & One time & 25 & 17 \\
\hline & Two Times & 60 & 40 \\
\hline & Three Times & 35 & 23 \\
\hline & More than three times & 30 & 20 \\
\hline & Total & 150 & 100 \\
\hline
\end{tabular}


Source: Primary Data * - Multiple Response

Table 2 exhibits that 46 per cent of the respondents are having savings account; a majority of 52 per cent of the respondents are general purpose user; 34 per cent of the respondents are maintaining their accounts between 3 years to 6 years of duration; 40 per cent of the respondents made a visit to the bank two times in a week.

\section{Credit Card:-}

\section{Products/ Services Availed Through Credit Cards}

The respondents are asked to state the products and services availed through credit cards. The same is exhibited in Table 3.

Table 3:- Products/ Services availed through Credit Cards

\begin{tabular}{|c|c|c|c|}
\hline Products / Services & Particulars & Number of Respondents & Percentage \\
\hline \multirow{4}{*}{ Products } & Consumer durables & 80 & 44 \\
\cline { 2 - 4 } & Home appliances & 27 & 15 \\
\cline { 2 - 4 } & Jewellery & 20 & 11 \\
\cline { 2 - 4 } & Dress Materials & 54 & 30 \\
\cline { 2 - 4 } & Total & $\mathbf{1 8 1}$ & $\mathbf{1 0 0}$ \\
\hline \multirow{5}{*}{ Services } & Rail/Air Ticket Booking & 60 & 37 \\
\cline { 2 - 4 } & Restaurant & 17 & 7 \\
\cline { 2 - 4 } & Hospital Expenses & 12 & 8 \\
\cline { 2 - 4 } & Shares/Debentures of selected & 13 & 12 \\
\cline { 2 - 4 } & companies & 20 & 26 \\
\cline { 2 - 4 } & Payment of Insurance Premium & 43 & $\mathbf{1 0 0}$ \\
\cline { 2 - 4 } & Utility Bills Payments & $\mathbf{1 6 5}^{*}$ & \\
\cline { 2 - 4 } & Total & & \\
\hline
\end{tabular}

\section{Source: Primary Data * Multiple Response}

It is clear from the Table 3 that a 44 per cent of the respondents are using the credit card for purchasing consumer durables; 37 per cent of the respondents are use the credit card for rail/air ticket booking.

\section{Reasons For Using Credit Cards}

Respondents are asked to rank reasons for using credit card. Based on the ranks that the respondents awarded, the researcher has found the number of responses placed in each rank. Using Garrett Ranking Technique, the researcher has computed the Garrett score and allotted ranks accordingly. Table 4 demonstrates the result.

Table 4:- Reasons for Using Credit Cards

\begin{tabular}{|c|c|c|c|}
\hline S.No & Reasons & Garret Score & Garret Rank \\
\hline 1 & Benefit of extended payment period & 8002 & 2 \\
\hline 2 & Benefit of converting purchase in to EMI & 7811 & 4 \\
\hline 3 & Benefit of Reward points or cash back. & 8545 & 1 \\
\hline 4 & Benefit of taking loan on card & 7849 & 3 \\
\hline 5 & Low charge & 6920 & 5 \\
\hline 6 & Avoid cash dealing & 6661 & 7 \\
\hline 7 & Easy to carry and make payment & 6862 & 6 \\
\hline
\end{tabular}

\section{Source: Computed Data}

Table 4 upshot that Benefit of reward points or cash back got the first rank with a maximum score of 8545; Benefit of extended payment period secured second rank with the score of 8002 and Avoid cash dealing occupied last rank with the minimum score of 6661 .

\section{Personal Profile And Level Of Satisfaction Of Customers Towards Credit Cards}

Seven statements are framed to obtain level of satisfaction of customers towards credit card. Likert's five point scaling techniques has been used to determine the level of satisfaction. Table exhibited the number of respondents under various level of agreement towards the statements. 
Table 5:- Level of Satisfaction.

\begin{tabular}{|l|l|l|l|l|l|l|l|l|}
\hline S.No & Particulars & \multicolumn{3}{|l|}{ No. of Respondents } & Mean & Std \\
\cline { 3 - 5 } & & SA & $\mathbf{A}$ & $\mathbf{N}$ & $\mathbf{D A}$ & SDA & & Deviation \\
\hline 1 & $\begin{array}{l}\text { Credit cards provide more convenience and wide } \\
\text { acceptance }\end{array}$ & 18 & 35 & 45 & 28 & 24 & 2.97 & 1.24 \\
\hline 2. & $\begin{array}{l}\text { Interest rate and other charges on credit card is } \\
\text { reasonable }\end{array}$ & 15 & 33 & 34 & 27 & 41 & 2.69 & 1.35 \\
\hline 3. & Comfortable to pay electrically/ telephone/ utility bills & 45 & 29 & 37 & 25 & 14 & 3.44 & 1.32 \\
\hline 4. & Credit limit on credit card is adequate & 25 & 17 & 17 & 40 & 51 & 2.5 & 1.47 \\
\hline 5. & Banks attend to credit card queries promptly & 28 & 22 & 25 & 45 & 30 & 2.8 & 1.40 \\
\hline 6. & Grievances of credit card holders settled satisfactorily & 35 & 28 & 34 & 33 & 14 & 3.33 & 1.33 \\
\hline 7. & $\begin{array}{l}\text { Knowing your spending Patten by way of regular } \\
\text { updated monthly bills }\end{array}$ & 38 & 33 & 23 & 34 & 22 & 3.21 & 1.42 \\
\hline
\end{tabular}

Source: Primary Data

Note: SA- Strongly Agree; A- Agree; N-Neutral; DA-Disagree; SDA-Strongly Disagree

The average score of Comfortable to pay electrically/ telephone/ utility bills(3.44), Grievances of credit card holders settled satisfactorily(3.33) and Knowing your spending Patten by way of regular updated monthly bills(3.21) is above three. It reveals that except these three statements, all the other statements are not agreed by the majority of the respondents.

\section{Chi Square Test:-}

The level of agreement of the respondents towards credit card has been classified into three categories viz., low level, medium level and high level.

The level of satisfaction has been derived from the mean score value of the 150 respondents. The calculated value of $\bar{X}$ and S.D. are 20.95 and 3.51 respectively. Therefore,

$$
\begin{aligned}
& \bar{X}+\mathrm{S} . \mathrm{D}=20.95+3.51=25 \text { and above }- \text { High Level } \\
& \bar{X}-\mathrm{S} . \mathrm{D}=20.95-3.51=17 \text { and below }- \text { Low Level } \\
& (\bar{X}+\mathrm{S} . \mathrm{D}) \text { to }(\bar{X}-\mathrm{S} . \mathrm{D})=17 \text { to } 25-\text { Medium Level }
\end{aligned}
$$

In order to analyse the relationship between demographic profile of the respondents and their level of satisfaction towards credit cards, chi-square test has been employed. The calculated value of chi square is compared with the table value of chi square at 5\% level of significance. If the calculated value of chi square test is more than the table value, the null hypothesis is rejected and vice versa.

\section{Hypothesis Testing 1:-}

$\mathrm{H}_{0} 1$ : There exists no significant difference between the Gender and the level of satisfaction towards credit card

\begin{tabular}{|c|c|c|c|c|}
\hline \multirow[t]{2}{*}{ Gender } & \multicolumn{3}{|c|}{ Level of Satisfaction } & \multirow[t]{2}{*}{ Total } \\
\hline & High & Medium & Low & \\
\hline Male & $28(26.0)$ & $44(45.0)$ & $23(24.1)$ & 95(95.0) \\
\hline Female & $13(15.0)$ & $27(26.0)$ & $15(13.9)$ & $55(55.0)$ \\
\hline Total & 41(41.0) & 71(71.0) & 38(38.0) & $150(150.0)$ \\
\hline \multirow[t]{2}{*}{ Chi-square } & Computed Value & DF & \multicolumn{2}{|l|}{ p value } \\
\hline & 0.620 & 2 & \multicolumn{2}{|l|}{0.734} \\
\hline
\end{tabular}
services. Here Chi-Square test is used as a tool to test it.

Table 6:- Gender and Level of Satisfaction of the Respondents.

Source: Computed Data; Figures within the parenthesis represent expected frequency

As $\mathrm{p}>0.05$, the null hypothesis is accepted at $5 \%$ level of significance. Hence, it is concluded that the level of satisfaction of the respondents towards credit card does not vary with gender. 


\section{Hypothesis Testing 2:-}

$\mathrm{H}_{0} 2$ : There exists no significant difference between the Age and the level of satisfaction towards credit card services. Here Chi-Square test is used as a tool to test it.

Table 7:- Age and Level of Satisfaction of the Respondents.

\begin{tabular}{|l|l|l|l|l|}
\hline \multirow{2}{*}{ Age (in years) } & \multicolumn{3}{c|}{ Level of Satisfaction } & \multirow{2}{*}{ Total } \\
\cline { 2 - 4 } & \multicolumn{1}{|c|}{ High } & \multicolumn{1}{c|}{ Medium } & \\
\hline Below 30 & $9(8.4)$ & $18(15.6)$ & $6(9)$ & $\mathbf{3 3 ( 3 3 . 0 )}$ \\
\hline $30-40$ & $21(16.5)$ & $28(30.8)$ & $16(17.8)$ & $\mathbf{6 5}(\mathbf{6 5 . 0})$ \\
\hline $41-50$ & $5(9.4)$ & $14(17.5)$ & $18(10.1)$ & $\mathbf{3 7}(\mathbf{3 7 . 0})$ \\
\hline Above 50 & $3(3.8)$ & $11(7.1)$ & $1(4.1)$ & $\mathbf{1 5}(\mathbf{1 5 . 0})$ \\
\hline Total & $\mathbf{3 8}(\mathbf{3 8 . 0})$ & $\mathbf{7 1}(\mathbf{7 1 . 0})$ & $\mathbf{4 1}(\mathbf{4 1 . 0})$ & $\mathbf{1 5 0}(\mathbf{1 5 0 . 0})$ \\
\hline Chi-square & Computed Value & DF & p value \\
\cline { 2 - 4 } & 16.645 & 6 & 0.011 & \\
\hline
\end{tabular}

Source: Computed Data; Figures within the parenthesis represent expected frequency

As $p<0.05$, the null hypothesis is rejected at $5 \%$ level of significance. Hence, it is concluded that the level of satisfaction of the respondents towards credit card vary with age of the respondents.

\section{Hypothesis Testing 3:-}

$\mathrm{H}_{0} 3$ : There exists no significant difference between the Marital Status and the level of satisfaction towards credit card services. Here Chi-Square test is used as a tool to test it.

Table 8:- Marital Status and Level of Satisfaction of the Respondents.

\begin{tabular}{|l|l|l|l|l|}
\hline \multirow{2}{*}{ Marital Status } & \multicolumn{2}{|l|}{ Level of Satisfaction } & \multirow{2}{*}{ Total } \\
\cline { 2 - 4 } & High & Medium & Low & \\
\hline Married & $28(26.6)$ & $50(49.7)$ & $27(28.7)$ & $\mathbf{1 0 5}(\mathbf{1 0 5 . 0})$ \\
\hline Unmarried & $10(11.4)$ & $21(21.3)$ & $14(12.3)$ & $\mathbf{4 5 ( 4 5 . 0 )}$ \\
\hline Total & $\mathbf{3 8}(\mathbf{3 8 . 0})$ & $\mathbf{7 1 ( 7 1 . 0 0 )}$ & $\mathbf{4 1 ( 4 1 . 0 0 )}$ & $\mathbf{1 5 0 ( 1 5 0 . 0 )}$ \\
\hline \multirow{2}{*}{ Chi-square } & Computed Value & DF & p value & \\
\cline { 2 - 5 } & 0.587 & 2 & 0.746 & \\
\hline
\end{tabular}

Source: Computed Data; Figures within the parenthesis represent expected frequency

As $p>0.05$, the null hypothesis is accepted at $5 \%$ level of significance. Hence, it is concluded that the level of satisfaction of the respondents towards credit card does not vary with marital status of the respondents.

\section{Hypothesis Testing 4:-}

$\mathrm{H}_{0} 4$ : There exists no significant difference between the occupation and the level of satisfaction towards credit card services. Here Chi-Square test is used as a tool to test it.

Table 9:- Occupation and Level of Satisfaction of the Respondents.

\begin{tabular}{|l|l|l|l|l|}
\hline \multirow{2}{*}{ Occupation } & \multicolumn{2}{|l|}{ Level of Satisfaction } & \multirow{2}{*}{ Total } \\
\cline { 2 - 4 } & High & Medium & Low & \\
\hline Businessman & $15(12.7)$ & $18(23.7)$ & $17(13.7)$ & $\mathbf{5 0 ( 5 0 . 0 )}$ \\
\hline Private Employee & $11(10.6)$ & $22(19.9)$ & $9(11.5)$ & $\mathbf{4 2 ( 4 2 . 0 )}$ \\
\hline Government Employee & $1(5.1)$ & $13(9.5)$ & $6(5.5)$ & $\mathbf{2 0}(\mathbf{2 0 . 0})$ \\
\hline Professionals & $4(4.6)$ & $9(8.5)$ & $5(4.9)$ & $\mathbf{1 8}(\mathbf{1 8 . 0})$ \\
\hline Housewives & $7(5.1)$ & $9(9.5)$ & $4(5.5)$ & $\mathbf{2 0}(\mathbf{2 0 . 0})$ \\
\hline Total & $\mathbf{3 8}(\mathbf{3 8 . 0})$ & $\mathbf{7 1 ( 7 1 . 0 )}$ & $\mathbf{4 1 ( 4 1 . 0 )}$ & $\mathbf{1 5 0}(\mathbf{1 5 0 . 0})$ \\
\hline Chi-square & Computed Value & DF & p value & \\
\cline { 2 - 4 } & 9.260 & 8 & 0.321 & \\
\hline
\end{tabular}

Source: Computed Data; Figures within the parenthesis represent expected frequency 
As $p>0.05$, the null hypothesis is accepted at $5 \%$ level of significance. Hence, it is concluded that the level of satisfaction of the respondents towards credit card does not vary with occupation of the respondents

\section{Hypothesis Testing 5:-}

$\mathrm{H}_{0}$ 5: There exists no significant difference between the income and the level of satisfaction towards credit card services. Here Chi-Square test is used as a tool to test it.

Table 10:- Income and Level of Satisfaction of the Respondents.

\begin{tabular}{|l|l|l|l|l|}
\hline \multirow{2}{*}{ Age (in years) } & \multicolumn{2}{|l|}{ Level of Satisfaction } & \multirow{2}{*}{ Total } \\
\cline { 2 - 4 } & High & Medium & Low & \\
\hline Less than Rs.5000 & $10(8.4)$ & $13(15.6)$ & $10(9.0)$ & $\mathbf{3 3 ( 3 3 . 0 )}$ \\
\hline Rs.5000 to Rs.10000 & $8(8.9)$ & $19(16.6)$ & $8(9.6)$ & $\mathbf{3 5 ( 3 5 . 0 )}$ \\
\hline Rs.10001 to Rs.15000 & $9(11.9)$ & $23(22.2)$ & $15(12.8)$ & $\mathbf{4 7 ( 4 7 . 0 )}$ \\
\hline More than Rs.15000 & $11(8.9)$ & $16(16.6)$ & $8(9.6)$ & $\mathbf{3 5}(\mathbf{3 5 . 0})$ \\
\hline Total & $\mathbf{3 8}(\mathbf{3 8 . 0})$ & $\mathbf{7 1 ( 7 1 . 0 )}$ & $\mathbf{4 1 ( 4 1 . 0 )}$ & $\mathbf{1 5 0 ( 1 5 0 . 0 )}$ \\
\hline Chi-square & Computed Value & DF & P value & \\
\cline { 2 - 4 } & 3.452 & 6 & 0.750 & \\
\hline
\end{tabular}

Source: Computed Data; Figures within the parenthesis represent expected frequency

As $p>0.05$, the null hypothesis is accepted at $5 \%$ level of significance. Hence, it is concluded that the level of satisfaction of the respondents towards credit card does vary with income level.

\section{Suggestions:-}

* Credit limit amount allowed by bank may be extended to certain extent to the deserving Credit card holders.

* Reduction of minimum eligibility criteria will attract the customers to obtain Credit Cards.

* Charges for the credit cards should be nominal.

* Awareness must be created about special offer available for maximum usage of credit cards.

\section{Conclusion:-}

Customer satisfaction in e-environment is determined by the website of the bank, efficiency of the bank, competency of the bank and information provided by the bank. Due to the complexity in the usage of credit cards, it is necessary to make the customers to know how to operate the credit cards for specific purpose. In order to facilitate the customers to carry the cards with them, effective protective measures must be taken to protect the cards against operational and security risk.

\section{References:-}

1. Dangwal RC, Kailash Sakalani and Swathi Anand (2010), E - Banking, Professional Banker, Jan - 2010, PP No. 26 - 33 .

2. Manas Ratha (1997), The Credit Card Model, MIT System, Dynamics in Education Project, June 16 - 1997, PP No. 01-33, (MIT - Massachusetts Institute of Technology).

3. Narindra Kumar Bhasin(2009), "Technology and Payment System", The Journal of Indian Institute of Banking and Finance, 80,17-21.

4. Ramalingam P (2009), Usage Pattern of Credit Card Holders, Indian Journal of Finance, April 2009 - 7, PP No. $07-14$.

5. Dr.S.Sudhagar(2012), “A Study on Perception and Awareness on Credit Cards among Bank Customers in Krishnagiri District”, IOSR Journal of Business and Management (IOSRJBM) ISSN: 2278-487X Volume 2, Issue $3,14-23$. 